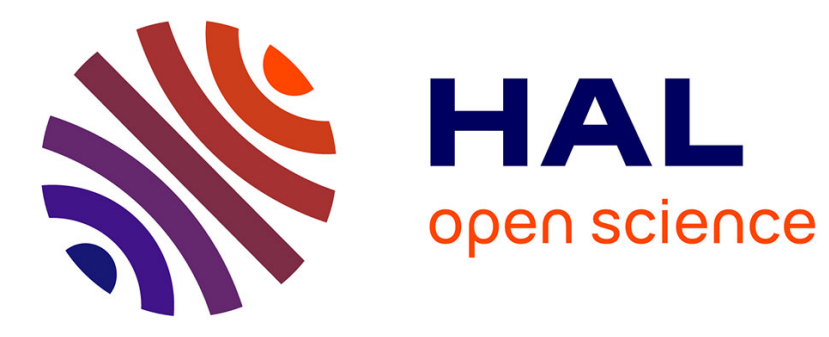

\title{
Understanding and Monitoring Reinsurance Counterparty Risk
}

Mathieu Gatumel, Sabine Lemoyne de Forges

\section{To cite this version:}

Mathieu Gatumel, Sabine Lemoyne de Forges. Understanding and Monitoring Reinsurance Counterparty Risk. Bulletin Français d'Actuariat, 2013, 13 (26), pp.121-138. hal-00946934

\section{HAL Id: hal-00946934 \\ https://hal.science/hal-00946934}

Submitted on 14 Feb 2014

HAL is a multi-disciplinary open access archive for the deposit and dissemination of scientific research documents, whether they are published or not. The documents may come from teaching and research institutions in France or abroad, or from public or private research centers.
L'archive ouverte pluridisciplinaire HAL, est destinée au dépôt et à la diffusion de documents scientifiques de niveau recherche, publiés ou non, émanant des établissements d'enseignement et de recherche français ou étrangers, des laboratoires publics ou privés. 


\title{
Understanding and Monitoring Reinsurance Counterparty Risk
}

\section{Literature review concerning reinsurance counterparty risk}

\author{
Mathieu Gatumel ${ }^{1}$ \\ University of Grenoble - CERAG
}

\author{
Sabine Lemoyne De Forges ${ }^{2}$ \\ Ecole Polytechnique
}

\begin{abstract}
Since 2008, catastrophic losses and financial turmoil have deeply shaken the insurance and reinsurance industries. Severe difficulties encountered by sector leaders like AIG and Swiss Re have shed light on the potential fragility of the players, and have increased attention on the subject of reinsurance counterparty risk. This corresponds to the exposure of an insurance company to reinsurer failure and is difficult to assess due to a scarcity of reliable measures. It has long been considered as largely auto-regulated by the insurance market. The impact of reinsurance credit on an insurers' balance sheet, market complexity and lack of coordinated responses among states begs questions concerning the role of control and regulation. In this article, we address the current state of reinsurance counterparty risk and existing means by which to measure it. We then discuss the impact of market discipline on this risk and point out the importance of control within the reinsurance industry. We particularly look at the key role of regulation in providing better risk measurement tools to assist in assessing the importance of reinsurance counterparty risk on insurance levels and the systematic development of risk management tools.
\end{abstract}

Keywords: Reinsurance Counterparty Risk, Solvency, Market Discipline, Regulation

JEL classification: G22, G28, G32, G33.

\footnotetext{
${ }^{1}$ Corresponding author. University of Grenoble - CERAG, 2, Place Doyen Gosse, 38031 Grenoble - France. Email: mathieu.gatumel@iut2.upmf-grenoble.fr

${ }^{2}$ Ecole Polytechnique, Economics Department. Palaiseau, France.
} 


\section{Introduction}

Even if insurance and reinsurance companies remained stable after the catastrophic losses, stock market volatility and decline in investment yields in 2010 and 2011, the 2008 financial crisis shed new light on the question of risk measurement and transfer in financial markets. The insurance industry has been deeply shaken, essentially on the asset side of its activity, as a result of events like the fall of AIG, the downgrade of Swiss Re and the resulting impact on means of alternative risk transfer. The question of insurance company exposure to reinsurance counterparty risk remains an important issue in insurance firm risk management.

In this article, we analyze the importance of default risk in light of recent events and discuss ways to mitigate it. Section 1 presents the state of the market and defines risk linked to reinsurer default. Section 2 explores current means of measuring counterparty risk, and highlights critical underlying issues. Section 3 discusses insurance industry market discipline concerning reinsurance counterparty risk. Finally, section 4 analyses current regulation solutions.

\section{A market with growing exposure to reinsurance default risk}

The reinsurance industry has greatly evolved over the last fifteen years. In 2007, some 150 reinsurance companies received a total premium volume of roughly $\$ 200$ billion (Standard and Poor's, 2011) and had a total capitalization estimated at $\$ 129$ billion for the last quarter of 2007 (Benfield Group, 2008). Historically, the reinsurance market has been dominated by specialized reinsurance companies, concentrated mostly in Europe and Bermuda and has been very intertwined on a worldwide level. Because transactions are primarily over the counter, information is scarce and difficult to obtain. Since the beginning of the nineties, reinsurance companies have become more intertwined. From 2003 to 2009, the market share of the ten first reinsurers (both Life and non-Life) rose from 56\% to $65 \%$ (Global Reinsurance Highlights report of Standard and Poor's, 2011). Details of this phenomenon for the top 5 reinsurers are given in Table (1). Guy Carpenter cited $59 \mathrm{M} \& \mathrm{~A}$ transactions in 2008 accounting for an aggregate value of $\$ 16.6$ billion.

Simultaneously, the past ten years have seen the downgrading of reinsurance companies as illustrated in Figure (1). This may be explained by a variety of factors: the cost of some particular events for the industry (Andrew, 9/11, Katrina), reserve strengthening for non-life reinsurers, purchase of certain reinsurers at inflated prices or under-performing equity markets. From this perspective, 2011 was particularly turbulent for insurance markets and was characterized by catastrophes that implied losses similar to those the reinsurance market sustained from U.S. hurricanes in 2004 and 2005. According to Aon - Benfield Group (2012), global property catastrophe losses for 2011 were estimated at $\$ 434$ billion. In addition, financial markets in 2011 were impacted by volatile stock market conditions, record low investment yields, downgrade of U.S. debt and the European sovereign debt crisis. Fortunately, most carriers avoided direct hits because of strong capital positions held for 3 or 4 
years. Nevertheless, for the future, external capital is likely to remain difficult and costly to acquire, and constraints on capital markets will force the industry to reconsider how to transfer it. For example, in 2011 , outstanding catastrophe bond issuances were equal to $\$ 4.6$ billion, below the level in 2006 . In 2008 and 2009, among the various reinsurers in the market, Swiss Re was strongly weakened by its financial activities, rendering Berkshire Hathaway's capital injection necessary as well as the purchase of an insurance cover. On the contrary, Munich Re conserved its rating whereas Berkshire Hathaway, following some financial losses due to its banking activity, was downgraded by two rating agencies.

Table (2) details the claim amounts due but not paid to the cedent by the reinsurance company for certain countries. The weight of balance sheet reinsurance recoverables on insurance companies, as well as on reinsurance market structure, point out the importance of studying reinsurance counterparty risk. According to the UK's Financial Services Authority definition, a credit risk is incurred whenever a firm is exposed to loss if a counterparty fails to perform its contractual obligations, including failure to perform in a timely manner. More precisely, a credit event may be classically defined as the failure for an issuer to pay a coupon or to redeem the principal value of an obligation on maturity date; it may also include filing for bankruptcy, insolvency, or compulsory restructuring (Swiss Re, 2003). Reinsurer bankruptcy may spring from three areas: risk subscription and investment policy as classically experienced by all insurance companies, retrocession, and risk credit exposure. Historically, there have been very few reinsurer bankruptcies: between 1980 and 2003, only 24 were enumerated by (Swiss Re, 2003) for a total gross premium corresponding to $\$ 820$ million (see Figure (2)). In fact, many bankruptcies are avoided by the fact that reinsurance companies put their investments into runoff before becoming insolvent.

In case of reinsurer default, an insurance company faces higher financial charges and difficulty reimbursing its insured clients in case of high claims. Few studies have focused on the way insurance companies take into account reinsurer credit risk. The question has been raised when considering optimal reinsurance contracts (Gajek and Zagrodny, 2004) for examining existing or changing regulations (Rossi and Lowe, 2002) and particularly in the case of the United States (Cole and McCullough, 2006; Cole et al., 2007). A liquid market for reinsurance claims does not exist and thus creditors are not allowed to modify their position depending on the credit risk of their reinsurers. This exposure may weaken the creditworthiness of one insurer, as was the case for Reliance Group Holdings: this US-based group collapsed when its exposure to reinsurance recoverables reached $600 \%$ of consolidated surplus at a time when no liquid assets were available and sub-investment grade debt was due for repayment (Benfield Group, 2007).

Global exposure of insurance companies to reinsurance credit risk may also weaken the industry as a whole, given its intertwined nature. Systemic risk (De Bandt and Hartmann, 2000) exists at industry or at economy levels. Van Lelyveld et al. (2009) estimate that among the risks introduced by use of reinsurance, credit risk is the single failure most likely to threaten financial stability of the concentrated reinsurance market and could induce large losses. Furthermore, retrocessions may increase the 
phenomena, as the London XL Spiral proved in the nineties. Burkart (2006) and Wade (2008) highlight that a chain of retrocessions built during the eighties weakened the industry, funneling underlying losses through a chain of Lloyd's syndicates, rendering them opaque and difficult to price. When the catastrophes occurred, losses were on a scale that threatened the whole industry. In 2005, the retrocession rate of reinsurance companies was estimated at $15 \%$ of ceded premiums (Group of Thirty, 2006). The limited number of reinsurers and their weaknesses to the same extreme shocks (on assets or liabilities) limited the likelihood that they could be responsible for a global systemic risk, but they were capable of weakening the insurance industry, esteemed the Group of Thirty (2006). The prospective study from Van Lelyveld et al. (2009) on the Dutch reinsurance market provides no evidence of reinsurance systemic risk. Nevertheless, the 2008 financial turmoil began by the failure of major financial firms and was characterized by a strong decrease of transactions in the market, requiring state intervention. This did not create a real systemic risk, but the consequences of financial firm bankruptcy on the situation cannot be ignored.

\section{The difficulty of quantifying and estimating counterparty risk}

Before monitoring reinsurance counterparty risk, one must have knowledge of such a risk. The modeling of default risk poses a number of challenges, especially in terms of information access. The reinsurance market is quite opaque, information on reinsurance company financial health being available mainly through rating agency notation. Extracting such information from financial markets remains difficult, as Burkart (2006) showed in his study of co-movements of default risk in the reinsurance industry. Issues related to estimating and modeling are as follows:

- Default probability: The probabilities of default within the market cannot be directly observed but need to be calculated based on either historical credit rating experience, deduced from a process involving certain forms of market prices, determined using a model of the underlying risk sources, or drawn from subjective credit assessment criteria.

- Default correlation: Directly modeling default correlation is challenging. This is due to the non-triviality of attempting to simulate correlated binary variables or to a lack of credible historical data for estimating default correlation directly. Flower et al. (2007) point out several sources of correlation to be taken into account when modeling the consequences of reinsurance default risk on a primary insurer's balance sheet. Shocks are the first source of correlation because reinsurers are broadly subject to common risks. Similarly, correlations between underwriting years introduce some temporal effects. Furthermore, the market is subject to wide cycle effects, in the sense that sustained soft cycle periods lead to growing reserve issues which can subsequently emerge as credit issues. This type of correlation is enhanced by the intertwined structure of the market: primary insurers and reinsurers are affected by the same types of events; domino effects may appear as a result of the different levels of retrocession. 
Additionally, capital requirement calculations at the extreme loss percentiles involve examination of the tails of asymmetric fat-tailed loss distributions. Is it particularly true for dependency issues that are difficult to capture for fat-tailed insurance risk distributions. Unfortunately, tools like copulae may appear irrelevant because of the limited available data which induce a high volatility when estimating them.

- Recovery rate: The main issue for its assessment is the difficulty to close an operation. As explained by Standard and Poor's (2008b), "an insurer may cease to write new risk but could spend years, sometimes decades, settling the liabilities that arise from the policies written before it closed its doors." In case of run-off, the entity may have difficulty raising capital. That explains why S\&P has developed run-off payment assessment which measures the capacity of an insurance company to pay its policies.

- Time horizon: all of these issues are reinforced by the long-term relationships between insurance and reinsurance companies. Indeed, the duration of insurance liabilities - and thus of reinsurance claims - covers many years. On the contrary, the measure of the underlying risks to the reinsurance credit risk, mainly catastrophic and financial risks, is generally limited to a short horizon.

Methodologies which aim at modeling reinsurance default risk take into account, more or less, the various issues. One of the first approaches proposed was cited by the "Bad Debt Paper"' (Bulmer et al., 2000) and adopted as a US actuary Advisory Note. It promotes factor-based deterministic provisions. The counterparty risk is captured through charge factors applied to expected recoveries. But, with the development of ICAS, Solvency II and Enterprise Risk Management (ERM), economic capital modeling has adopted a more prospective view. The various solutions for modeling reinsurance counterparty risk are detailed in Figure (3). We distinguish between two types of model. The first relies on a financial model of credit risk, as promoted by Flower et al. (2007) and by Sachs (2007), where one is confronted with the difficulty of dealing with reinsurance credit risk portfolios that are much less diversified than typical banking credit portfolios. The second type is based on actuarial foundations and models shocks on the reinsurance market at a high level, as in Grinda and Nguyen (2006), or in a more schematic way in Ter Berg (2008).

Recent development of several models illustrates the fact that assessment of reinsurance counterparty risk is a difficult task and that work is in progress, upheld and moved ahead by the necessity for monitoring risk.

\section{The market discipline for reinsurance default risk}

Considering the recent impacts of the financial crisis, as well as past crises, the question of the need to regulate reinsurance counterparty risk must be addressed. As Harrington (2005) describes, the 
rationale for government intervention must respond to the following considerations (introduced by Breyer (1982)): the potential for market failure in a competitive market must be assessed and there must be positive benefits to regulation. Thus a preamble to the question of regulation is the study of market discipline on reinsurance counterparty risk. This involves, on one hand, reinsurers' capability to monitor their solvency risk, and on the other hand, the capacity of insurance companies to selfmonitor their exposure to reinsurance counterparty risk.

As regards the reinsurance industry, Epermanis and Harrington (2006) point out several features of the market that plead for a certain level of discipline. Standard agency considerations as well as litigation costs provide incentives for reinsurers to limit their default risk. In addition, as highlighted by Jean-Baptiste and Santomero (2000), the reinsurance market is characterized by long-term relationships between insurers and reinsurers. Moreover, transactions take place between two wellinformed players. Rossi and Lowe (2002) insist on the differences between the insurance and reinsurance industries, arguing that insurance companies are more capable of evaluating reinsurers' products than are customers when faced with evaluating insurers' products. Thus, in markets based on trust, as in the financial services industry, reinsurer self-discipline is all the more necessary because they exercise a business-to-business activity. For example, several studies have shown the impact of quality on reinsurance treaties regulating pricing and contracting. Zanjani (2002) considers a theoretical model where risk neutral reinsurers with limited liability face a demand for insurance conditional on quality that explains their choice of a level of internal capital limiting default risk. Furthermore, econometric studies have shown that there exists a slight premium for credit risk. Weiss and Chung's (2004) results support the risky debt hypothesis that consumers are concerned with the financial strength of reinsurers, as demonstrated by policyholders' surplus, past profit or loss on ordinary activities and new capital all of which are related to reinsurance prices.

As for the exposure of insurance companies to reinsurance counterparty risk, the same standard arguments may apply to reinsurance companies concerning self-regulation: agency consideration, protection of the franchise value, debt holder monitoring risk management, and consumer demand for long-term relationships with insurers, all provide incentives to insurance companies to monitor their own default risk and in doing so, their reinsurance coverage and the inherent counterparty risk. The empirical study of Epermanis and Harrington (2006) documents that rating downgrades of U.S non-life insurance companies are followed by revenue declines in comparison with insurers that did not experience rating downgrades ${ }^{3}$. This highlights the importance of insurer financial strength. The rise of risk management over the last ten years has lead to the development of techniques that may be used to mitigate this counterparty risk. Table (3) synthesizes them. Classical tools include those usually used for the monitoring of reinsurance coverage. Diversification of reinsurance companies as a means used to cover risk allows mitigating counterparty risk. Self-retention management, often used in a cost reduction perspective, may also address the issue. On one hand, higher retention increases the

\footnotetext{
3 Note that there is also a rational for risk-loving behaviors, particularly when companies face high insolvency risk in a system where there is a guaranty fund. Bohn and Hall (1999) provide evidence of high premium growth for more than one third of US $\mathrm{P} \& \mathrm{C}$ insurance companies in the two years before their failures.
} 
capital requirement due to non-transferred risk, and thus the corresponding cost of capital, but reduces the ceded premiums; on the other hand it increases the capital requirement due to reinsurance counterparty risks and the corresponding cost of capital, but it also increases the ceded premiums. This arbitrage between expected profit and certainty equivalent raises a central question for firms concerning their risk appetite. Obviously, with growing interest for risk management having been identified by the Benfield Group (2008), knowledge of reinsurance counterparty risk is also taken into consideration.

Following Plantin (2006), a size-based distinction has to be made between insurance companies. Reinsurance companies do not merely offer external capital to cover extreme risk, they also provide risk expertise to their customers. In the case of relatively small companies, reinsurers are unavoidable partners for risk management. Therefore, since medium or large companies have begun to develop real risk management expertise, they no longer rely as heavily on reinsurance company knowledge. New tools have also been tried to mitigate reinsurance default risk.

Development of the catastrophe bonds market represented a way to diversify catastrophe coverage without being subject to reinsurance default risk. However, default risk on catastrophe bonds is not zero: it is subject to the counterparty risk of the swap, as illustrated by the consequences of the Lehman Brothers downfall which caused the default of four catastrophe bonds in 2008. With the development of financial instruments to cover credit risk, direct coverage tools have been available for insurers: insurers or reinsurers have been using Credit Default Swaps for some time (Sawyer, 2006). Yet not all insurers use them, some arguing that the markets are still too young. More sophisticated products have even been structured to allow for hedging a portfolio of credit risks. In 2007, Hannover Re issued a CDO of reinsurance recoverables. However, the credit crisis has demonstrated the difficulty in pricing and structuring this kind of product, a difficulty enhanced when considering a tail risk such as reinsurance default risk. Furthermore, due to its complexity, the cost of such coverage would be relatively high compared to the expected loss from reinsurer default.

Furthermore reinsurance counterparty risk remains a rare risk that only large insurance companies seem to have the luxury to study. Section 3 showed that measuring reinsurance counterparty risk is delicate, mostly due to imperfect information on the dependency between actors, between long tail risks, and between insurance and financial risks. This limited knowledge of risk handicaps development of an efficient market discipline. Regulation, however, allows partially solving this issue and is necessary to reveal it.

\section{The modalities and rules of regulation}

Reinsurance insurance has always been an opaque market and its culture relies on trust built between cedents and their reinsurers in the framework of a long-term relationship. Since the early 1990s, many changes have occurred in the market. It has become increasingly intertwined due to market 
concentration. There are a few main actors in a very global field. The underlying risks have also evolved, as market locations have changed with the birth of the Bermudians. Furthermore, management styles have evolved, with the more traditional saxon model giving way to the anglosaxon one, as highlighted by Albert (1991). In this context, the recent financial crisis has pointed out the need to reconsider reinsurance default risk regulation, particularly when reinsurance giants like Swiss Re have been shaken by recent events.

Revealing information on reinsurance counterparty risk seems central to answering regulation questions, as reliable information concerning market discipline is necessary. There is thus a real place for regulators in developing better risk understanding, through increased information sharing within reinsurance markets. Until now, part of this information has been provided by rating agencies. The Group of Thirty (2006) characterizes these agencies as de-facto-regulators. Although their estimation of reinsurance counterparty risk remains very limited, it should not be taken for granted. Global questioning of their role in the current crisis seems relevant when considering precisely this case. There are three different levels of regulator action that have been taken in different countries. These actions respond unequally to the question of information disclosure. Table (4) provides a summary of the different observed means of regulation and their benefits and drawbacks.

The first possibility is direct regulation at the reinsurance market level. Such regulation is not always advocated, as noted by Harrington (2005) who estimates that as the reinsurance industry has greater self-discipline than either the insurance or banking industries, solvency and capital requirements should be consequently less restrictive. Evolution of this discussion is noticeable at several levels. In the European Union, Solvability II includes capital requirements for reinsurance counterparty risk. Furthermore the Reinsurance Directive, adopted in 2005, implemented a common regulatory system which particularly aims at incorporating reinsurance into the EU's supervisory system of the insurance industry (Evans, 2007).

A second possibility is to regulate contracts between insurers and their reinsurers. This is predominantly the case for reinsurance companies originating from countries outside the jurisdiction of the cedant. It stems from a desire to fully protect the cedant, and thus the final consumers, from the reinsurance counterparty risk when not being controlled by the same authority. Discussions are underway in the US on collateralization requirements for unauthorized reinsurance companies ${ }^{4}$ that have the obligation to fully collateralize gross US liabilities.

Finally, regulation concerning the level of insurance is possible, obliging insurers to immobilize capital corresponding to the risk and to their management possibilities. Regulators may have an interesting catalyst role when creating new measures for risk, as is the case in the European Union, with the SCR calculation. Such measures can augment insurance company interest in risk monitoring. It develops research for new tools and methodologies, and eventually leads to the disclosure of more information

\footnotetext{
${ }^{4}$ According to Guy Carpenter's website, we can define authorized reinsurance as the reinsurance placed with a reinsurer which is licensed or otherwise recognized by a particular state insurance department. We call an insurer or reinsurer domiciled outside the U.S. but conducting an insurance or reinsurance business within the U.S., an Alien Company.
} 
by reinsurers concerning their default risk. Even if large insurance companies are already relatively autonomous in their risk management, it can be particularly useful for small insurance companies.

Notwithstanding the different possible means of regulation, some key questions must be addressed when opting for regulation. First, the cost of regulating should be carefully considered. Some companies like Swiss Re (2003), or researchers like Arnold (2008), argue that regulation may limit capacity: it is explicit for strong alien reinsurers whose capacity could be of use, if the capital requirement increases to provide protection. Moreover, the market does not seem to value solvency protection. Cole et al. (2007) point out the absence of a relation between use of unauthorized reinsurance and prices. In any case, intensively regulating reinsurance insolvency risk implies additional costs (Harrington, 2005), among them an increase of the cost of reinsurance. Strict reinsurance regulation implies higher costs of reinsurance, and capital immobilization at the insurer level to take into account reinsurance counterparty risk is costly as well. All these costs are ultimately passed on to the insured parties. Advocating regulation of this risk implicitly recognizes the role of the reinsurance industry in spreading global risk.

The question of reinsurance counterparty risk can indeed be addressed in a more global regulation question. This includes the degree to which insurance companies should be protected from reinsurance counterparty risk, as well as the degree to which reinsurance regulation should allow the disappearance of not sufficiently sound insurers or reinsurers in case of crisis. Global harmony in regulation could be beneficial for the reinsurance industry, due to their business model that rests on the widest possible diversification and distribution of risk. Rossi and Lowe (2002) point out that there is no central regulation of the reinsurance industry: it differs from one country to another, and mutual recognition is uncommon. As analyzed by Alexander et al. (2006), the IAIS has certainly promoted some basic standards for reinsurance supervision by encouraging coordination between national regulators, but they have not been introduced by all countries. The Group of Thirty (2006) and Evans (2007) highlight the importance of reinsurance for the financial stability of the insurance industry. They underscore the advantages of regulation at a regional level, at least to ease risk transfers. Going further, Vogelgesang and Kubicek (2007) advocate global supervision of reinsurance companies: reinsurer eligibility to conduct business should be determined by a single body and monitored frequently . Furthermore, national supervision regimes should be compatible. The role of supervisors to pay attention to signs indicating need for intervention also remains important. In the case of the insurance industry, Bohn and Hall (1999) exploit pre-insolvency data to detect premium patterns before insolvency; they find evidence that a large percentage of firms grow quickly before failure.

An alternative to direct regulation would be increased market discipline (Harrington, 2005), encouraging stakeholders to pay more attention to default risk. Regulation at the European level deals with this issue in two ways, first by obliging insurers to assess the capital charge relative to reinsurer default risk (to this end, Solvency II eases transparency and allows the development of standards). Second, being characterized by a capital charge, each reinsurer is encouraged to control its financial 
strength. At the market level, such regulation is more able to improve market discipline than use of collaterals which do not make reinsurers aware of their responsibilities - the collateral amount depends roughly on financial health - and directly limits access to the market.

\section{Conclusion}

Trust is the basis for insurance and reinsurance industry interactions. Considering the weight of reinsurance recoverables on insurer balance sheets, the increase of insurance risks, and the turmoil in financial markets - particularly related to risk transfers - reinsurance counterparty risk has to be carefully monitored. Market discipline, existant due to the particularities of the market, is not, however, sufficient to monitor this tail risk.

In this context, a certainty remains. Insurance companies have to develop strong expertise concerning their own risks to be able to decide which risks they are not able to support and thus determine their exposure to reinsurance counterparty risk. Ongoing regulation definitely plays an important role in clarifying this issue through development of proper risk measures to establish capital ratios - if possible on the reinsurance level - and elucidation of reinsurance company responsibilities.

Nosce te ipsum (Know thyself)

Socrates 


\section{References}

- Albert, M. (1991). Capitalisme contre Capitalisme. Editions du Seuil.

- Alexander, K., Dhumale, R., and Eatwell, J. (2006). Global Governance of Financial Systems: The International Regulation of Systemic Risk. International Association of Insurance Supervisor (IAIS), p.61-65. Oxford University Press.

- Aon - Benfield Group (2012). Reinsurance Market Outlook: Value Creating Capital. Technical report.

- Arnold, G. S. (2008). The Reinsurance Collateral Debate and 2008 Proposed Regulatory Reform Efforts. "The Year in Review 2008" - American Bar Association.

- Benfield Group (2007). Looking for a Premium - Reinsurance Credit Risk and Bond Default Rates. Benfield Industry Analysis and Research. Technical Report.

- Benfield Group (2008). Global Reinsurance Market Review. Benfield Industry Analysis and Research. Technical Report.

- Benfield Group (2009). Reinsurance Market Outlook: Global Prices Firm as Reinsurers Maintain Core Capital Amid Credit Crisis. Benfield Industry Analysis and Research. Technical Report.

- Bohn, J. G. and Hall, B. J. (1999). The Moral Hazard of Insuring the Insurers. In Froot, K., editor, The Financing of Catastrophe Risk, chapter 1, pages 363-390. The University of Chicago Press.

- Brett, P. and Singh, D. (2005). Credit Risk and Reinsurers. Risk Insights 3 (9), GenRe.

- Breyer, S. (1982). Regulation and its Reform. Cambridge, Mass: Harvard University Press.

- Britt, S. and Krvavych, Y. (2009). Reinsurance Credit Risk Modelling. In Proceedings of the 2009 Astin Conference.

- Bulmer, R., Gallagher, C., Green, P., Hart, D., Matthews, P., Moss, G., and Sheaf, S. (2000). Reinsurance Bad Debt Provisions for General Insurance Companies. General Insurance Research Organising Committee.

- Burkart, O. (2006). Are there Comovements in the Default Risk of Reinsurance Companies? Risk Management and Insurance Review, 9(2):275-297.

- CEIOPS (2008). QIS 4 Technical Specifications. Technical report.

- CEIOPS (2009). Draft CEIOPS's Advice for Level 2 Implementing Measures on Solvency II: SCR Standard Formula - Counterparty Default Risk Module. Technical report.

- Cole, C. R. and McCullough, K. A. (2006). A Reexamination of the Corporate Demand of Reinsurance. Journal of Risk \& Insurance, 73(1):169-192.

- Cole, C. R., McCullough, K. A., and Powell, L. (2007). Regulation of Reinsurance Recoverables: Protection or Protectionism?

- De Bandt, O. and Hartmann, P. (2000). Systemic Risk: a survey. European Central Bank-Working Paper Series, (35).

- Epermanis, K. and Harrington, S. E. (2006). Market Discipline in Property/Casualty Insurance: Evidence from Premium Growth Surrounding Changes in Financial Strength Ratings. Journal of Money, Credit and Banking, 38(6):1515-1544.

- Evans, A. (2007). The EU Reinsurance Directive. The Geneva Paper on Risk \& Insurance Issues \& Practices, 32:95-104.

- Flower, M., Afify, M., Cook, I., Gosrani, V., James, G., Koulovasipoulos, P., Lincoln, J., Maneval, D., and Robinson, J. (2007). Reinsurance Counterparty Credit Risks - Practical Suggestions for Pricing, Reserving and Capital Modelling. 34th annual GIRO Convention.

- Gajek, L. and Zagrodny, D. (2004). Reinsurance Arrangements Maximizing Insurer's Survival Probability. Journal of Risk \& Insurance, 71(3):421-435.

- Grinda and NGuyen (2006). Modèle du Risque de Contrepartie des Réassureurs d'une Compagnie d'Assurance. International Congress of Actuaries.

- Group of Thirty (2006). Reinsurance and International Financial Markets. Technical report, Group of Thirty.

- Guy Carpenter \& Company, Inc. (2009a). Reinsurance Market Review. Technical report.

- Guy Carpenter \& Company, Inc. (2009b). World Catastrophe Reinsurance Market 2009. Technical report.

- Harrington, S. E. (2005). Capital Adequacy Beyond Basel: Banking, Securities, and Insurance, chapter in Capital Adequacy in Insurance and Reinsurance. Oxford University Press.

- Jean-Baptiste, E. L. and Santomero, A. M. (2000). The design of private reinsurance contracts. Journal of Financial Intermediation, 9(3):274-297.

- Plantin, G. (2006). Does reinsurance need reinsurers? The Journal of Risk and Insurance, 73(1):153-168. 
- Rossi, M.-L. and Lowe, N. (2002). Regulating Reinsurance in the Global Market. The Geneva Papers on Risk and Insurance - Issues and Practices, 27(1):122-133.

- Sachs, R. (2007). Reinsurance Credit Risk. Technical report, Münchener Rück.

- Sawyer, N. (2006). Convergence on Credit. Risk, 19(6).

- Shaw, R. (2007). The Modelling of Reinsurance Credit Risk. 34th annual GIRO Convention.

- Standard and Poor's (2005). Global Reinsurance Highlights - 2005 Edition. Technical report, Standard and Poor's.

- Standard and Poor's (2006). Global Reinsurance Highlights - 2006 Edition. Technical report, Standard and Poor's.

- Standard and Poor's (2008a). 2007 Annual Global Corporate Default Study and Rating Transitions. Ratings direct, Standard and Poors.

- Standard and Poor's (2008b). Criteria: New Insurance Run-Off Payment Assessments Evaluate Capacity to Pay After an Entity Closes. Technical report, Standard and Poor's.

- Standard and Poor's (2008c). Global Reinsurance Highlights - 2008 Edition. Technical report, Standard and Poor's.

- Standard and Poor's (2011). Global Reinsurance Highlights - 2011 Edition. Technical report, Standard and Poor's.

- Swiss Re (2003). Reinsurance - a Systemic Risk? Technical report, Sigma, Swiss Re, Economic Research and Consulting.

- Ter Berg, P. (2008). Portfolio Modelling of Counterparty Reinsurance Default Risk. Life \& Pensions, 4:29-33.

- Van Lelyveld, I., Liedorp, F., and Kampman, M. (2009). An Empirical Assessment of Reinsurance Risk. Working Paper 201/2009, De Nederlandsche Bank NV.

- Vogelgesang, R. and Kubicek, M. (2007). Towards a Global Aprroach to Reinsurance Regulation. The Geneva Papers on Risk and Insurance - Issues and Practices, 32:413-425.

- Wade, M. (2008). Lloyd's and the Parallels with the Banking Crisis. Financial Times.

- Weiss, M. A. and Chung, J.-H. (2004). U.S. Reinsurance Prices, Financial Quality, and Global Capacity. Journal of Risk \& Insurance, 71(3):437-467.

- Zanjani, G. (2002). Pricing and capital allocation in catastrophe insurance. Journal of Financial Economics, 65(2):283-305. 
Tables and Figures

\begin{tabular}{|c|c|c|c|c|c|c|c|}
\hline \multicolumn{2}{|c|}{ Reinsurance Company } & 2003 & 2004 & 2005 & 2006 & 2007 & 2008 \\
\hline \multicolumn{2}{|l|}{ MunichRe } & $14.90 \%$ & $14.80 \%$ & $13.80 \%$ & $15.80 \%$ & $16.80 \%$ & $16.80 \%$ \\
\hline \multicolumn{2}{|l|}{ SwissRe } & $12.70 \%$ & $14.40 \%$ & $12.90 \%$ & $13.70 \%$ & $15.30 \%$ & $14.10 \%$ \\
\hline \multicolumn{2}{|c|}{ BerkshireHathawayRe } & $6.10 \%$ & $5.90 \%$ & $6.10 \%$ & $6.70 \%$ & $9.60 \%$ & $5.90 \%$ \\
\hline \multicolumn{2}{|l|}{ HannoverRe } & $5.20 \%$ & $5.70 \%$ & $5.60 \%$ & $5.40 \%$ & $5.90 \%$ & $7.00 \%$ \\
\hline \multicolumn{2}{|c|}{ GEInsuranceSolutions $^{5}$} & $5.00 \%$ & $4.60 \%$ & $4.10 \%$ & & & \\
\hline \multicolumn{2}{|l|}{ Lloyd's } & $4.00 \%$ & $3.60 \%$ & $4.00 \%$ & $4.90 \%$ & $4.60 \%$ & $3.90 \%$ \\
\hline \multicolumn{8}{|c|}{$\begin{array}{l}\text { Table 1: Market shares of the } 5 \text { biggest reinsurers from } 2003 \text { to } 2007 . \\
\text { Source: Standard and Poor's. }\end{array}$} \\
\hline Pays & 2000 & 2001 & 2002 & 2003 & 2004 & 2005 & 2006 \\
\hline Belgium & $12 \%$ & $13 \%$ & $14 \%$ & $14 \%$ & $15 \%$ & $14 \%$ & $15 \%$ \\
\hline France & $10 \%$ & $14 \%$ & $11 \%$ & $12 \%$ & $12 \%$ & $12 \%$ & $13 \%$ \\
\hline Germany & $21 \%$ & $21 \%$ & $22 \%$ & $20 \%$ & $19 \%$ & $20 \%$ & $18 \%$ \\
\hline Italy & $14 \%$ & $12 \%$ & $12 \%$ & $13 \%$ & $13 \%$ & $13 \%$ & $10 \%$ \\
\hline Netherlands & $15 \%$ & $15 \%$ & $16 \%$ & $15 \%$ & $12 \%$ & $10 \%$ & $11 \%$ \\
\hline Royaume-Uni & $34 \%$ & $33 \%$ & $32 \%$ & $29 \%$ & $29 \%$ & $29 \%$ & $25 \%$ \\
\hline
\end{tabular}

Table 2: Evolution of the part of reinsurance recoverables in the insurance company balance sheets.

\begin{tabular}{lc}
\hline \multicolumn{1}{c}{ Level } & Techniques \\
\hline Monitor reinsurance coverage & $\begin{array}{c}\text { Diversification of reinsurance companies } \\
\text { Management of self-retention level } \\
\text { Collateral }\end{array}$ \\
Diversify catastrophe coverage & Catastrophe Bonds \\
& CDS for reinsurers with highest level of coverage \\
& CDO of reinsurance recoverables
\end{tabular}

Table 3: Risk management techniques to monitor reinsurance counterparty risk

\begin{tabular}{|c|c|c|c|c|}
\hline Level & Mean & Description & Pros/Cons & Where \\
\hline Insurers & SCR & Internalization of Risk & $\begin{array}{l}\text { May arise interest in risk knowledge } \\
\text { May limit it to the SCR calculation } \\
\text { Formula not always adapted }\end{array}$ & EU \\
\hline Reinsurers & Solvability & Standards & $\begin{array}{l}\text { No need to regulate a business sector } \\
\text { Risk of false security to cedant }\end{array}$ & EU \\
\hline Contracts & Clauses & $\begin{array}{l}\text { State Licence } \\
\text { If not, collateral obligations or } \\
\text { Letter of Crédit }\end{array}$ & $\begin{array}{l}\text { No need to verify soundness of RI but costlier } \\
\text { and less quantity restriction }\end{array}$ & US \\
\hline
\end{tabular}

Table 4: Level of regulation for reinsurer counterparty risk

\footnotetext{
${ }^{5} \mathrm{GE}$ Insurance Solutions has been acquired in 2006 by Swiss $\mathrm{Re}$.
} 


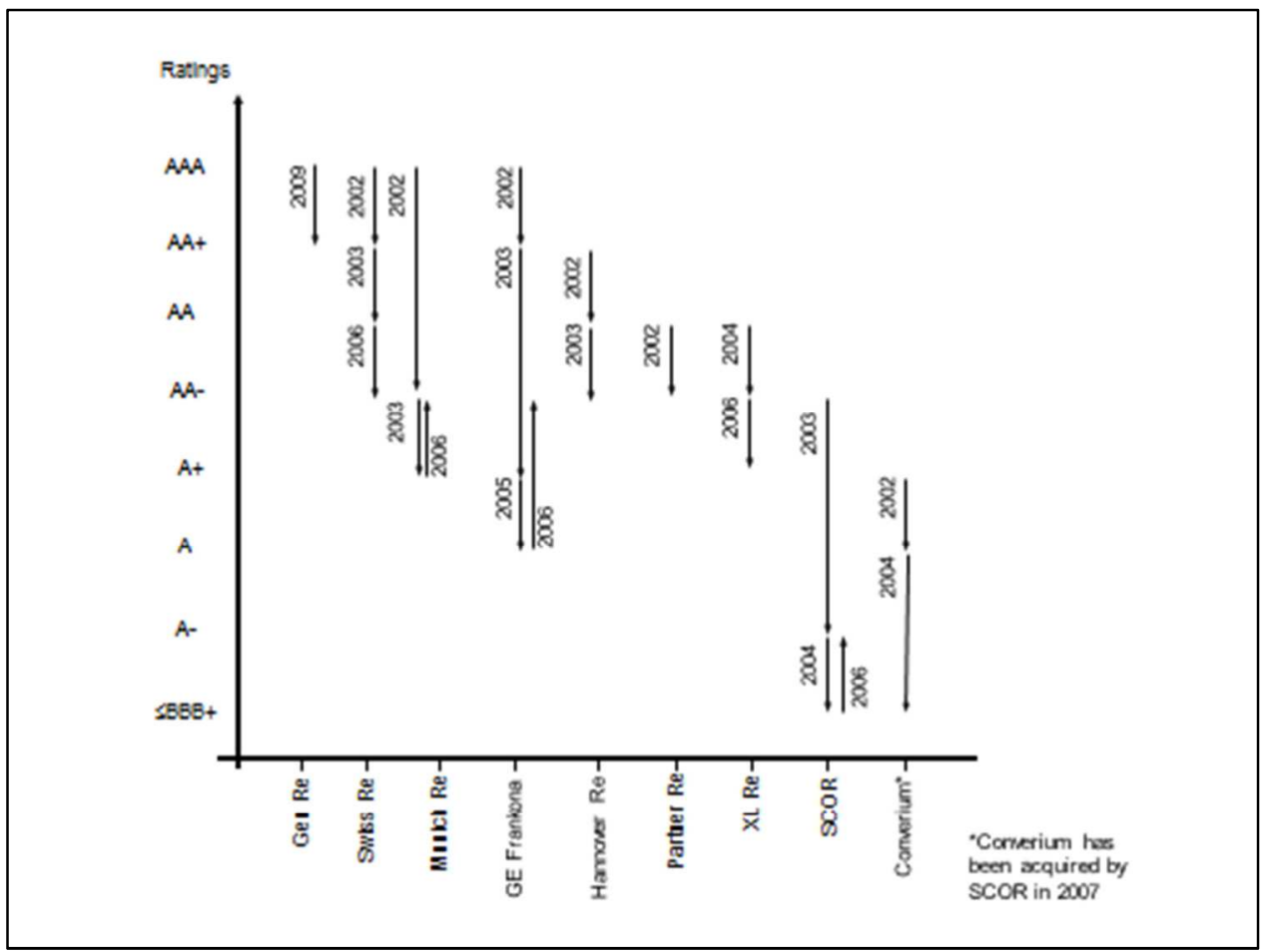

Figure 1: Reinsurer downgrades from 2002 to the _rst semester of 2011. Source: Bloomberg, Brett and Singh (2005).

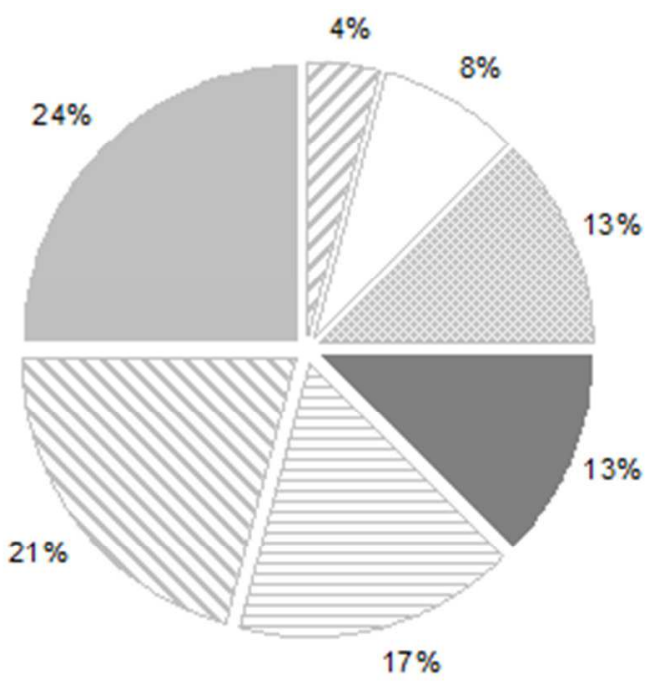

$\square$ Retrocessionnaire default

$\square$ Unde fined

$3 \%$ Insufficient capital

Insufficient reserves

$\exists$ Fraud

D Losses from LMX Spiral

$M$ ism anage ment, poor und erwiting

Figure 2: Sources of reinsurer defaults.

Source: Swiss Re (2003). 


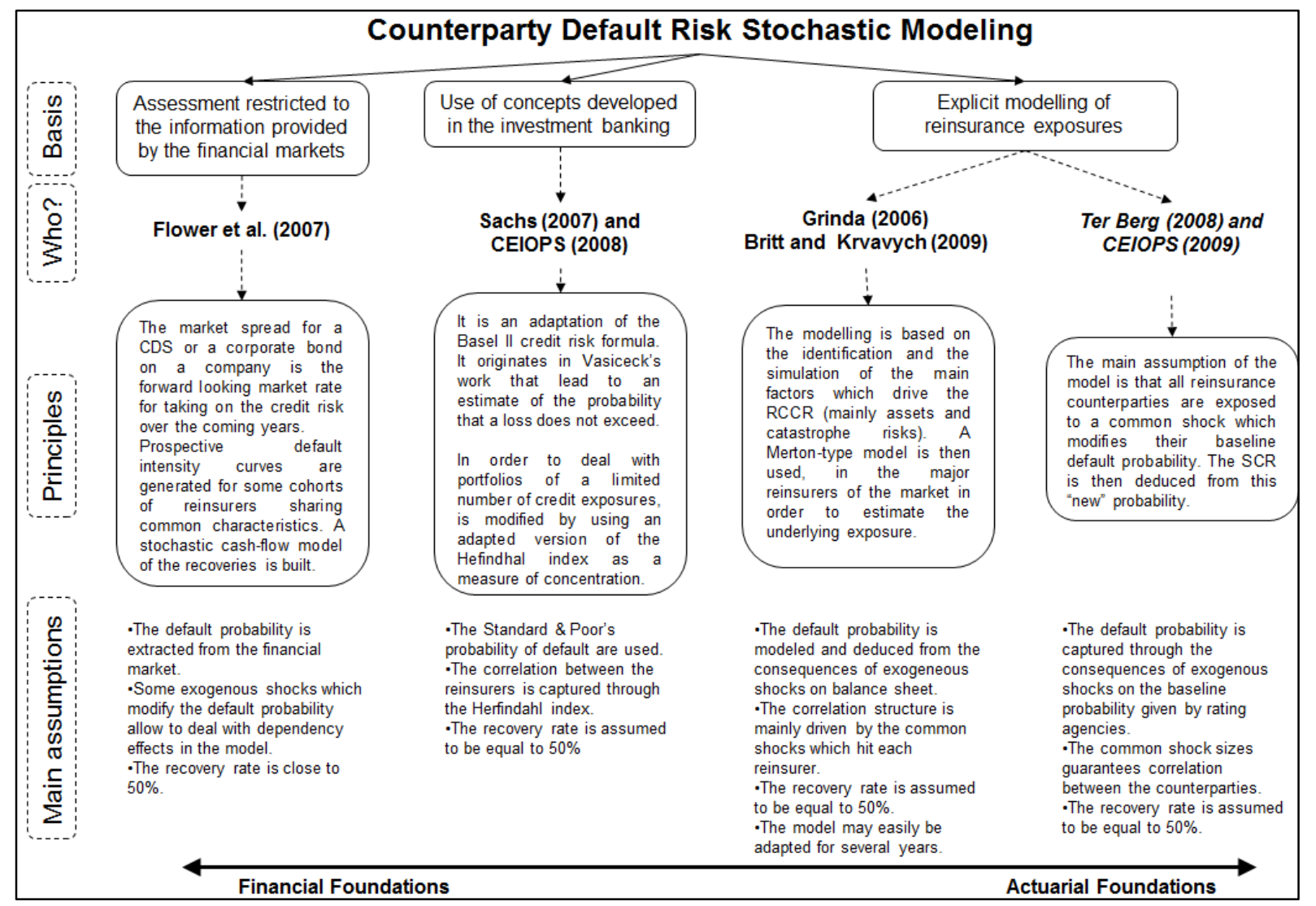

Figure 3: Main assessment methodologies of the reinsurer counterparty risk. 